\title{
Peningkatan Kualitas dan Pemanfaatan Limbah Hasil Pembuatan VCO (Virgin Coconut Oil) IKM Rumah Ikhtiar
}

\author{
Rosdiani Azis $^{1 *}$, Ikrima Staddal ${ }^{1}$, Syahmidarni Al Islamiyah ${ }^{1}$ \\ ${ }^{1}$ Politeknik Gorontalo \\ Jl. Muchlis Rahim Panggulo Barat Bone Bolango 96112 Gorontalo \\ *E-mail : rosdiani@poligon.ac.id
}

\begin{abstract}
Abstrak
Desa Posso merupakan salah satu desa yang berada di Kecamatan Kwandang, melalui Badan usaha milik desa membentuk IKM sukses bersama yang memproduksi minyak kelapa tradisional. Tujuan kegiatan pengabdian ini adalah untuk meningkatkan kualitas minyak kelapa tradisional beserta limbahnya dan manajemen usaha mitra. Hasil dari kegiatan pengabdian ini diperoleh beberapa mesin seperti mesin pengupas kelapa dengan rerata pengupasan kelapa sekitar $18 \mathrm{~s} /$ buah pada kecepatan mesin $2000 \mathrm{rpm}$ dan poros $25 \mathrm{rpm}$, mesin pemeras santan kapasitas besar dengan pengoperasian manual lewat tenaga hidroli, mesin pengaduk VCO dengan daya tampung 20 liter dengan kecepatan putar 900 rpm sampai 4200 rpm, mesin destilasi etanol dengan daya tampung 30 liter yang dilengkapi dengan kondensor, drum pembakaran tempurung menjadi arang, desain kemasan dan label produk, akun jual beli online dan pengoperasiannya telah mitra dapatkan.
\end{abstract}

Kata Kunci : limbah, VCO, industri kecil menengah, pengabdian masyarakat

\begin{abstract}
Posso Village is one of the villages located in Kwandang District, through a village-owned enterprise formed a successful IKM together that produces traditional coconut oil. The purpose of this service activity is to improve the quality of traditional coconut oil and its waste and the management of partner businesses. The results of this service activity obtained several machines such as a coconut peeler machine with an average coconut peeling of about $18 \mathrm{~s} /$ piece at a machine speed of $2000 \mathrm{rpm}$ and a shaft $25 \mathrm{rpm}$, a large capacity coconut milk squeezer machine with manual operation via hydraulic power, a VCO mixer machine with a capacity of 20 liters with a rotational speed of $900 \mathrm{rpm}$ to $4200 \mathrm{rpm}$, an ethanol distillation machine with a capacity of 30 liters equipped with a condenser, a drum for burning shells into charcoal, product packaging and label designs, online trading accounts and operations have been obtained by partners.
\end{abstract}

Key Words : waste, virgin coconut oil, small scale industries, community services

\section{PENDAHULUAN}

Kelapa (Cocos nucifera L.) merupakan salah satu tanaman perkebunan yang paling banyak dibudidayakan di Provinsi Gorontalo. Berdasarkan data yang dilaporkan oleh Badan Pusat Statistik (BPS) Provinsi Gorontalo. Tanaman ini tersebar di 4 kabupaten yakni Kabupaten Gorontalo $22.810 \mathrm{Ha}$, Kabupaten Pohuwato 14.312 Ha, Kabupaten Gorontalo Utara 8.528 Ha dan Kabupaten Boalemo 6.862 Ha. Desa Posso merupakan Desa penghasil kelapa terbesar di Kabupaten Gorontalo Utara. Jenis kelapa yang dibudidayakan di Posso adalah kelapa dalam, genjah dan hibrida. Potensi kelapa di Desa ini mencapai 15.000 butir perbulannya.
Potensi kelapa ini terhitung cukup besar dan dapat dimanfaatkan oleh masyarakat desa untuk membentuk lapangan kerja baru yang dapat menyokong roda perekonomian desa khususnya dalam meningkatkan pendapatan masyarakatnya.

Kelapa mempunyai daya guna yang luas karena selain sebagai bahan baku industri pangan dan non pangan juga sebagai konsumsi rumah tangga. Pendayagunaan kelapa tidak hanya sebagai minyak goreng tetapi ada beberapa produk olahan kelapa lain yang menjadi mata dagang dipasar internasional antara lain, kelapa parut, santan segar, arang tempurung, gula kelapa dan minyak kelapa murni atau yang dikenal dengan sebutan Virgin Coconut Oil (VCO) 
(Nursyam et al., 2013).

Rumah Ikhtiar merupakan IKM (Industri Kecil Menengah) yang melakukan pengolahan kelapa yang memfokuskan pada pengolahan VCO, adapun IKM ini memiliki filosofi sebuah tempat berusaha berkreasi dengan mandiri, berkumpul serta belajar menyatukan ide dan asil olahan menjadi satu produk bersama. IKM Rumah Ikhtiar ini sebagian besar beranggotakan ibu-ibu rumah tangga (kalangan muda dan lansia) dan bapak-bapak pengepul (pengumpul) kelapa. Dengan adanya IKM ini diharapkan dapat memberdayakan masyarakat Desa khususnya ibuibu rumah tangga (istri petani) agar mempunyai pekerjaan sampingan yang dapat menjadi potensi pendapatan yang signifikan bagi kesejahteraan hidupnya (Gambar 1).

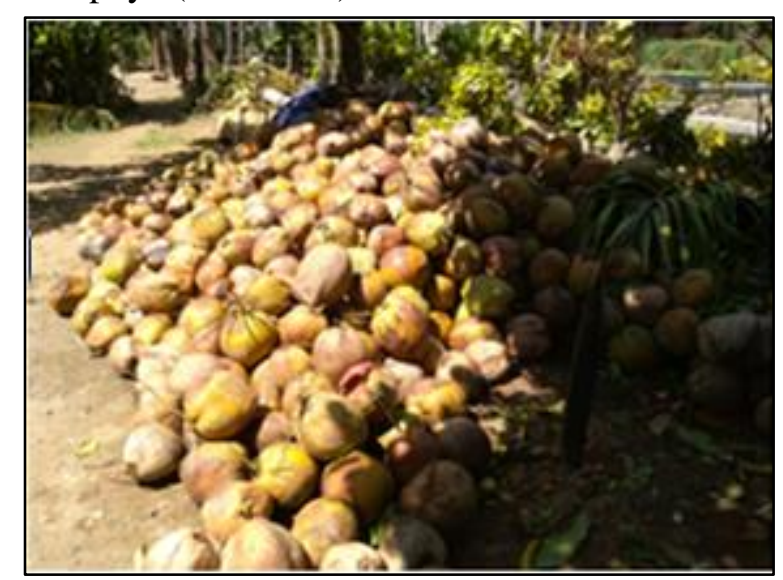

Gambar 1. Hasil Panen Kelapa Desa Posso

Secara umum IKM ini mampu mengolah VCO (Virgin Coconut Oil) sebanyak 20 botol perbulan, tampilan produk VCO secara pengemasan terlihat menarik dan VCO yang telah dikemas dengan berat bersih $200 \mathrm{ml}$ seharga $\mathrm{Rp} 60.000$ perbotol. Dalam 1 bulan IKM Rumah Ikhtiar mampu menjual VCO sekitar 20 botol dengan penghasilan kurang lebih $\mathrm{Rp} 1.200 .000$ diluar biaya produksi setiap bulannya, hasil penjualan biasanya digunakan untuk produksi berikutnya. Produk VCO yang dihasilkan oleh IKM ini telah berdasarkan hasil survey tim pengabdian Politeknik Gorontalo. Ada beberapa kendala yang dihadapi oleh IKM Rumah Ikhtiar untuk berkembangkan produk VCO diantaranya : (1) Pemerasan santan masih manual; (2) Santan yang dihasilkan tidak homogen sehingga kualitas rendah; (3) Produk belum ada uji laboratorium tentang komposisi kimia VCO; (4) Hasil limbah VCO tidak dimanfaatkan; (5) Pemasaran yang belum maksimal.
Potensi pemasaran VCO sangatlah besar mengingat kandungan produk ini yang sangat bermanfaat bagi kesehatan dan dapat digunakan sebagai bahan tambahan kosmetik. Namun untuk IKM ini melakukan produksi jika ada pesanan saja, sehingga perlu untuk melakukan perbaikan agar pemasaran VCO menjadi lebih luas lagi. Berdasarkan uraian tersebut, kendala yang dihadapi oleh kelompok pembuat VCO perlu ditangani secara komprehensif, agar potensi lokal berupa kelapa dapat dimanfaatkan secara maksimal. Untuk mewujudkan hal tersebut, maka tim pengabdian Politeknik Gorontalo dapat membantu meningkatkan kualitas VCO sehingga dapat meningkatkan pendapatan beserta produk hasil limbahnya secara khusus dan mampu menunjang roda perekonomian masyarakat Desa Posso pada umumnya melalui Program Kemitraan Masyarakat (PKM).

\section{METODE}

Rencana kegiatan pengabdian ini dimulai dengan kesepakatan kerja sama antara tim pengabdi dari Politeknik Gorontalo dengan khalayak sasaran (mitra) yaitu IKM Rumah Ikhtiar. Tim pelaksana pengabdian pada masyarakat ini merupakan sinergi dari dosen prodi Teknologi Hasil Pertanian dan Prodi Mesin Peralatan Pertanian yang mempunyai keahlian berbeda-beda. Dengan sinergi yang baik dari tim pengusul maka kegiatan ini akan berjalan dengan lancar dan akan tercapainya target luaran yang diharapkan. Untuk mendukung kelancaran dan keberhasilan pengabdian, kegiatan pengabdian ini didukung oleh sarana dan prasarana di Politeknik Gorontalo, sebagai berikut:

1. Bengkel kerja di Prodi Mesin dan Peralatan Pertanian

2. Laboratorium Analisa Pangan di Prodi Teknologi Hasil pertanian

3. Laboratorium Sucofindo Cabang Cibitung Bekasi

Pelaksanaan kegiatan pengabdian dilakukan dalam enam tahap yakni: (1) Sosialisasi kegiatan disertai penjelasan secara teori tentang mesin yang akan digunakan dalam pengolahan VCO dan limbahnya serta teori pembuatan VCO; (2) Praktek penggunaan mesin pemeras santan dan mesin sentrifugasi; (3) Praktek pembuatan VCO; (4) Pembuatan arang aktif dan etanol; (5) Pengujian laboratorium terhadap komposisi kimia VCO, etanol dan arang aktif; (6) Pelatihan manajemen pemasaran. Pelaksanaan kegiatan 
dilaksanakan secara bertahap dengan maksud agar proses alih ilmu pengetahuan dan teknologi dari tim pengabdi kepada IKM lebih gampang dan mudah dipahami.

\section{HASIL DAN PEMBAHASAN Pelaksanaan Kegiatan}

Pelaksanaan agenda PKM telah diadakan oleh Tim pengabdi Politeknik Gorontalo telah mencapai keberhasilan, hal ini tidak lepas dari kerja sama semua tim, terkhusus kepada pihak pihak mitra (sasaran) yakni UKM Rumah Ikhtiar. Adapun Pelaksanaan kegiatan dilakukan di Bulan Juni-Oktober 2021.

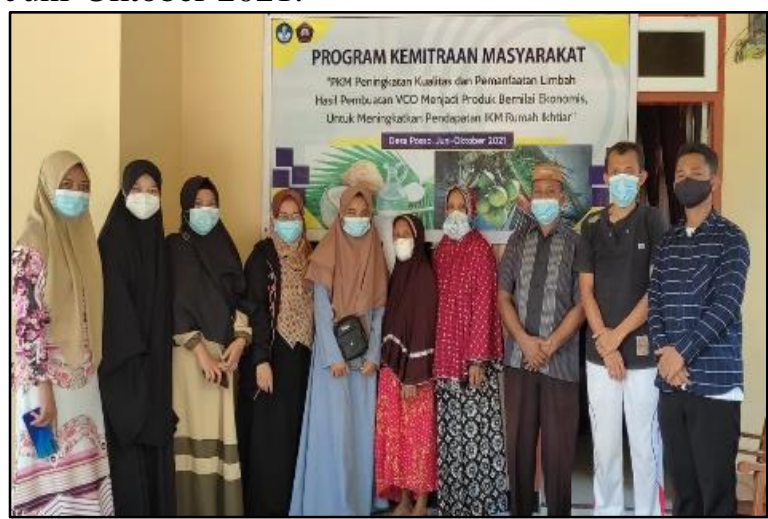

Gambar 2. Dokumentasi Tim dan Warga Masyarakat

Kegiatan dilaksanakan dalam bentuk pelatihan pembuatan alat pemeras $\mathrm{VCO}$, mesin pembuatan sentrifus santan, mesin destilasi etanol air kelapa, alat pembakaran arang, pelatihan pemasaran dan manajemen usaha. Adapun tahapan pelaksanaan adalah sebagai berikut :

1. Kegiatan ini dilaksanakan dengan suasana informal, kegiatan dimulai dengan perbicangan santai bersama Kepala Desa Posso, anggota UKM Rumah Ikhtiar. Kegiatan ini dihadiri sekitar 12 peserta. Pada ini tim menyampaikan maksud kehadiran dan penyampaian tentang program PKM serta kegiata apa saja yang akan dilaksanakan yakni, pembuatan alat alat pemeras VCO, Mesin pembuatan sentrifus santan, Mesin destilasi etanol air kelapa, pembuatan alat pembakaran arang, analisis kimia VCO, etanol dan arang, serta pelatihan pemasaran dan manajemen usaha.

2. Diskusi juga dirahkan pada pembahasan tantang bagaimana produksi vco, produksi etanol dan produksi arang dan hal ini disampaikan secara diskusi kepada tim UKM dan Kepala desa.
3. Kegiatan dilanjutkan dengan melihat kondisi rumah produksi dan mengecek VCO yang sudah dihasilkan oleh UKM.

4. Selain diskusi dengan Mitra, Tim Pengabdi juga melakukan penyerahan Face hild dan Masker untuk fasilitas keamanan dalam kondisi pandemi, sebagai pengaman saat melakukan produksi VCO, etanol dan arang.

\section{Peralatan Pemeras Santan}

Beberapa kendala yang dihadapi oleh IKM Rumah Ikhtiar untuk berkembangkan produk $\mathrm{VCO}$; diantaranya pemerasan santan masih manual menggunakan tangan sehingga dibutuhkan alat pemeras untuk mempercepat proses pemerasan santan, sehingga hal ini juga dapat meningatkan proses pembuatan VCO. Adapun solusi yang diberikan adalah dengan pemberian alat pemeras santan kepada Mitra UKM, adapun alat ini telah di berikan kepada mitra.
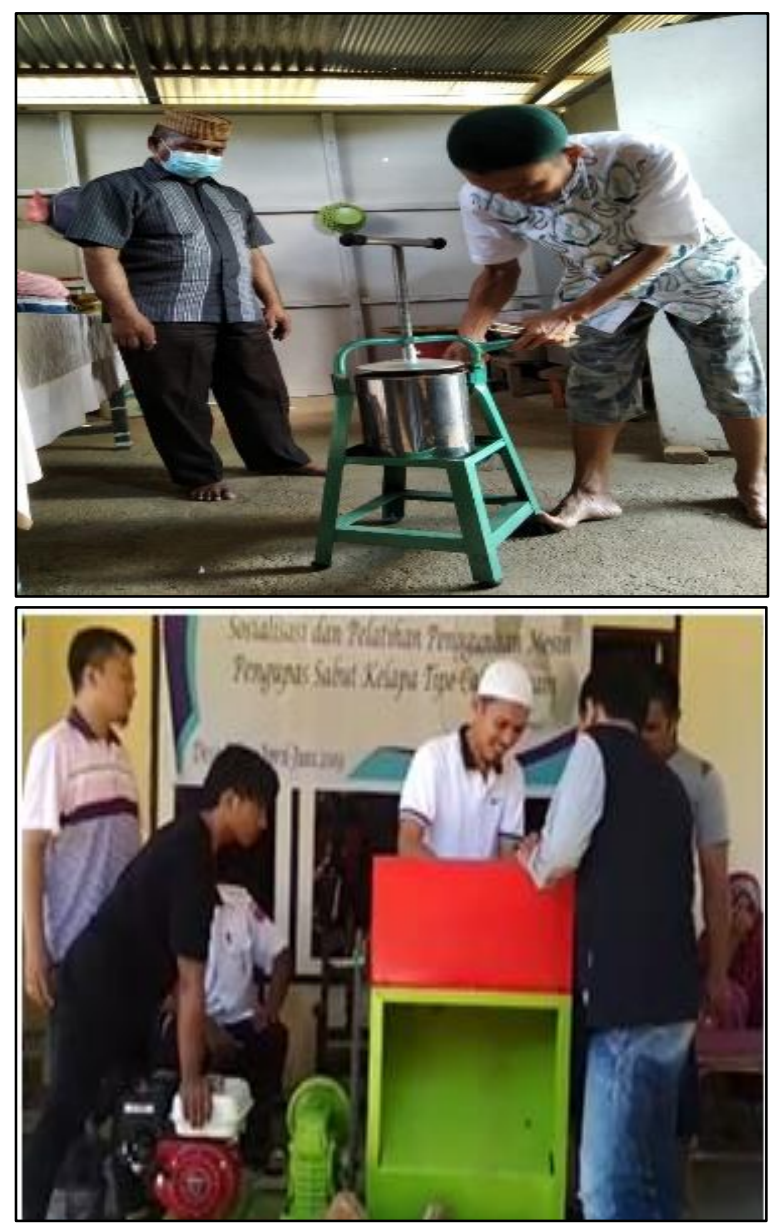

Gambar 3. Alat Peras Santan Hidrolik dan Penyerahan Alat kepada IKM 
Peras santan hidrolik merupakan suatu mesin yang digunakan untuk memeras santan dalam kapasitas besar dengan cara yang mudah dan lebih praktis. Pemeras santan jenis ini digunakan dalam proses pemerasan santan menggunakan cara manual dengan menekan lewat tenaga hidrolik dalam sebuah mesin. Pemeras santan hidrolik PS15 dapat di gunakan untuk proses pemerasan santan dengan jumlah kapasitas mesin dapat menampung sekitar 15 butir kelapa untuk satu kali prosesnya. Tampilan pemeras santan hidrolik PS15 memiliki dimensi mesin dalam detail panjang mesin $44 \mathrm{~cm}$, lebar dalam $36 \mathrm{~cm}$ serta ketinggian mesin yakni $144 \mathrm{~cm}$. Dalam desainnya pemeras santan hidrolik PS-15 dilengkapi dengan tabung dengan diameter berukuran $22 \mathrm{~cm}$ dengan tinggi dalam $33 \mathrm{~cm}$. Untuk mempermudah proses kinerja pemeras santan hidrolik PS-15 dilengkapi dengan tenaga pompa hidrolik dalam ukuran berat 4 ton.

Adapun cara kerja alat pengaduk ini adalah dengan menghilangkan stabilitas protein dengan terdenaturasinya sehingga tingkat kelarutannya berkurang menyebabkan protein mengalami koagulasi dan akhirnya akan mengalami pengendapan, sehingga lapisan minyak dan air dapat terpisah. Hal ini sesuai dengan pendapat (Winarno, 1997). Bahwa salah satu penyebab hilangnya stabilitas protein adalah adanya pengadukan. Hal ini berarti bahwa protein mengalami denaturasi sehingga kelarutannya berkurang. Lapisan molekul protein bagian dalam yang bersifat hidrofob berbalik ke luar, sedangkan bagian luar yang bersifat hidrofil terlipat ke dalam. Hal ini menyebabkan protein mengalami koagulasi dan akhirnya akan mengalami pengendapan, sehingga lapisan minyak dan air dapat terpisah.

\section{Pengolahan Limbah}

Dalam proses pengolahan VCO masih diperoleh produk samping/limbah berupa tempurung kelapa, ampas kelapa dan air kelapa belum diolah sama sekali, sehingga oleh TIM PKM memberikan alternatif pengolahan hasil produk hasil samping tersebut sehingga dapat memberikan nilai ekonomi dan memanfatkan limbah hasil VCO. Adapun produk yang dihasilkan dari tempurung dan sabut adalah arang, sehingga tim memberikan pengetahuan tentang teori pembuatan arang dan membuat alat pembakaran arang. Adapun untuk air kelapa diolah menjadi etanol. Tim Pengabdi memberikan pengetahuan teori dan memberikan alat berupa alat destilasi etanol. Mesin destilasi etanol memiliki daya tampung air kelapa mencapai 30 liter. Mesin ini dilengkapi dengan kondensor berupa pipa pendingin sepanjang $2 \mathrm{~m}$, wadah pendingin yang berisi air, wadah penampung air, pompa celup untuk proses sirkulasi air pada kondensor, rangka mesin yang terbuat dari paduan besi holo dan pelat, tabung gas, kompor gas, dan pipa keluaran etanol. Air kelapa yang digunakan dalam mesin ini harus dicampur dengan ragi terlebih dahulu selama $2 \times 24$ jam. Perbandingan yang digunakan adala $1 \mathrm{~g}$ ragi untuk 1 liter air kelapa. Untuk tempurung, tim mengubahnya menjadi arang. Arang ini dapat dijual dirumah makan atau masyarakat yang akan memasak dengan menu ikan bakar. Harga arang dipasaran mencapai Rp 6.000 - Rp 9.000/kg. Harga ini fluktuatif tergantung permintaan pasar dan musim kelapa. Untuk membuat arang, caranya sangat mudah. tempurung dibakar didalam drum.
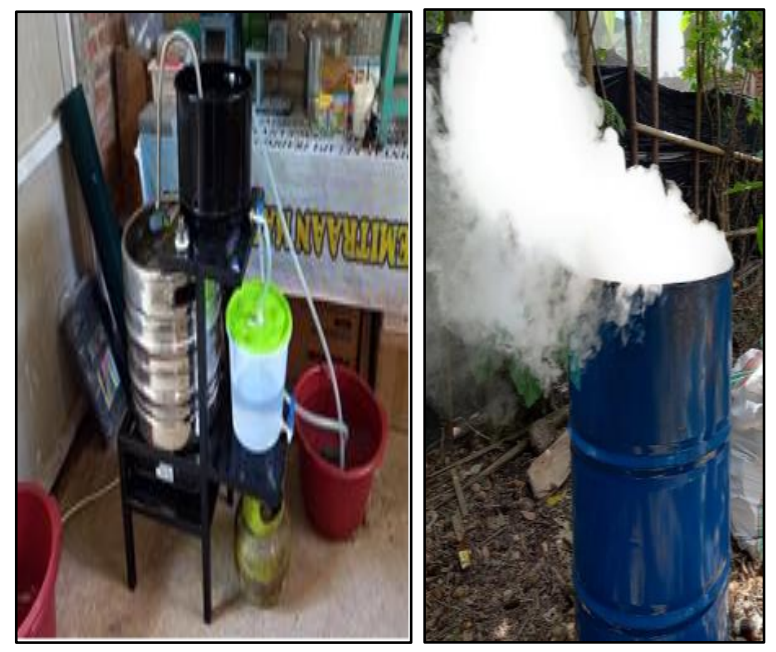

Gambar 4. (a) Alat destilasi; (b) Alat drum pembakaran arang

\section{Komposisi Kimia VCO, Arang dan Etanol}

Pengujian komposisi VCO sangat penting dalam rangka mengetahui kandungan gizi yang dimiliki oleh produk, hal ini juga karena prasayarat untuk memasuki pasar luas dibutuhkan legalitas bahwa produk aman dari kandungankandungan berbahaya, apalagi dalam kondisi hari ini, masyarakat sudah mulai selesktif dalam memiliki produk, khususnya untuk konsumsi harian. Dengan demikian tim melakukan pengujian VCO yang telah dihasilkan oleh pihak IKM MITRA. Adapun kualitas VCO yang diuji terdiri atas kadar air, kadar kotoran, bilangan penyabunan, asam lemak, dan asam-asam yang terkandung dalam $\mathrm{VCO}$, misalnya asam laurat, 
asam palmitat dan lain-lain. Pengujian ini telah dilakukan di Laboratorium Sucofindo Bekasi namun hasil pengujian belum selesai karena adanya kendala PPKM saat proses pengujian. Hal yang sama kami lakukan terhadapat 2 produk hasil samping yakni pengujian kualitas arang dan etanol. Untuk arang dilakukan pengujian di Laboratorium Sucofindo Bekasi, sementara untuk mengetahui kandungan presentase etanol yang dihasil, pengujian dilakukan di Laboratorium Teknologi Hasil Pertanian Politeknik Gorontalo. Hasil uji etanol dengan 3 kali ulangan, diperoleh etanol $10 \%$ untuk hasil produk air kelapa. Adapun untuk arang aktif yang akan diteliti adalah kadar air, kadar abu dan ketebalan arang sedangkan untuk etanol yang diteliti adalah presentase jumlah kandungan etanolnya. Kemudian hasil uji tersebut diserahkan kepada mitra sebagai acuan kualitas produk yang mereka miliki.

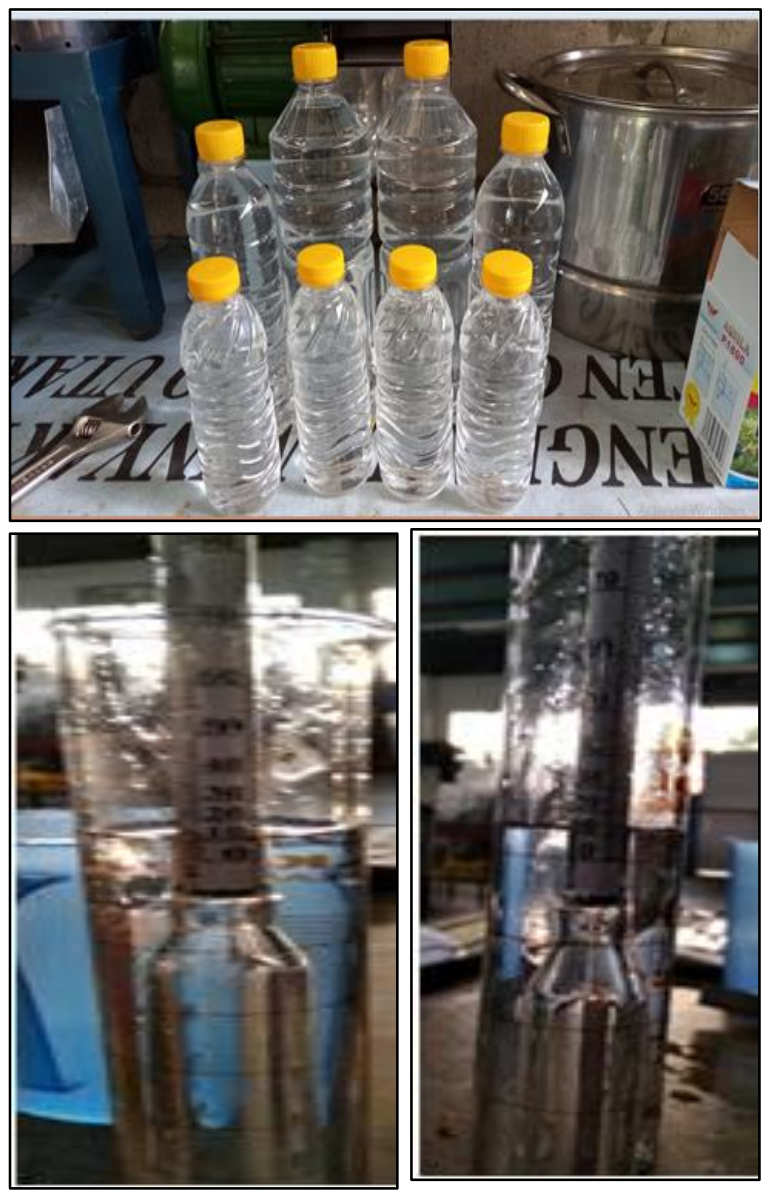

Gambar 5. Etanol 10\% dan Pengujian Etanol

\section{Pelatihan Manajemen Usaha dan Pemasaran}

Tahapan kegiatan ini dilakukan untuk memberikan pengetahuan bagaimana strategi pemasaran kepada mitra mulai dari mendesain kemasan produk, pelabelan, membuat akun situs jual beli online dan media sosial dan cara mengoperasikannya. Setelah kegiatan ini dilakukan, mitra telah mampu mendesain kemasan produk dan label, memiliki akun penjualan online serta mampu mengoperasikan akun tersebut dengan baik.
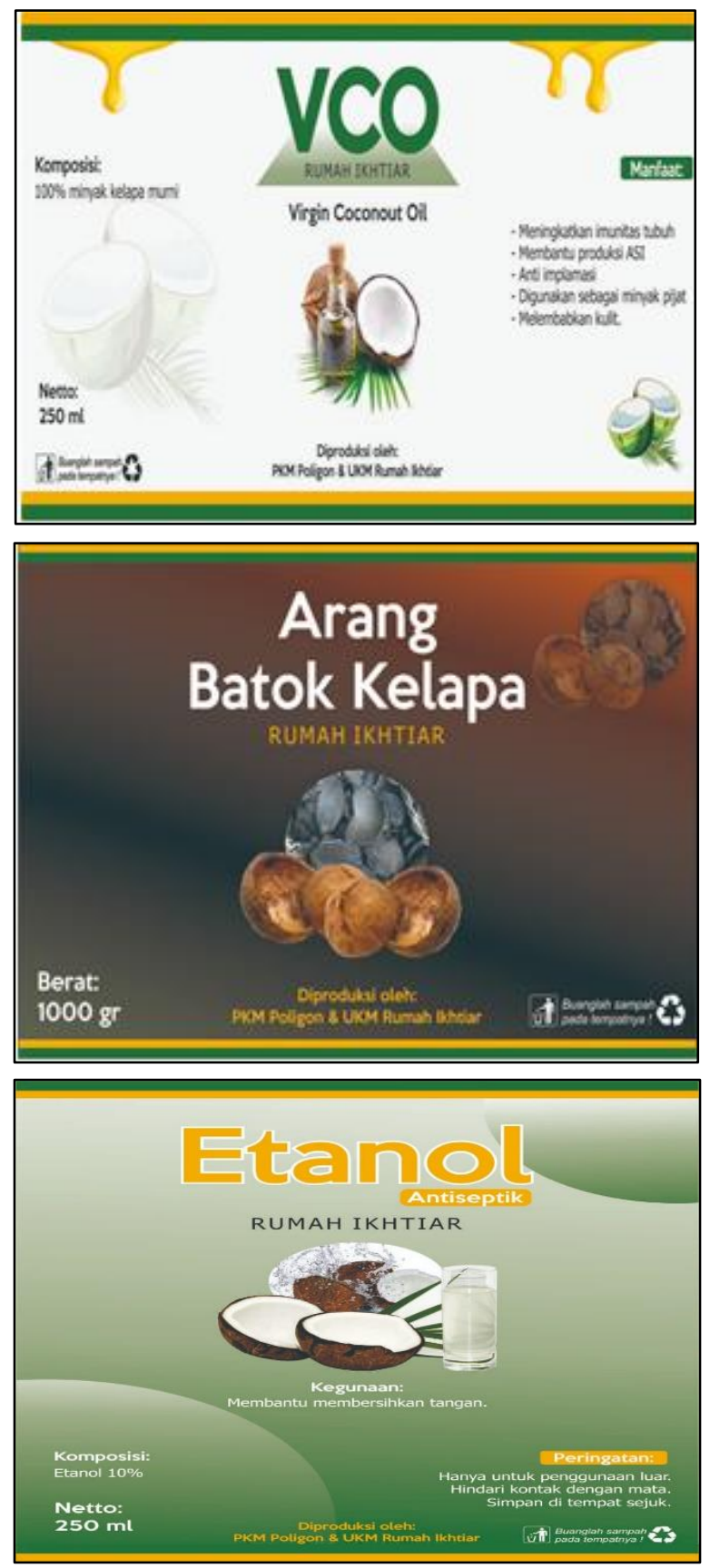

Gambar 6. Label Kemasan VCO, Arang dan Etanol untuk Antiseptik

\section{KESIMPULAN}

Berdasarkan uraian di atas, maka dapat disimpulkan bahwa semua tahapan kegiatan 
pengabdian berjalan dengan lancar sesuai tujuan yang diharapkan. Hasil dari kegiatan pengabdian ini diperoleh beberapa mesin pengolahan $\mathrm{VCO}$ (mesin pengupas sabuk, pemeras santan, pengaduk santan, mesin pengolah limbah, mesin destilasi etanol dan drum pembakaran tempurung). Selanjutnya mitra juga telah memiliki pengetahuan pengemasan dan manajemen pemasaran melalui pelatihan yang diberikan oleh tim pengabdian seperti desain kemasan dan label produk, akun jual beli online dan pengoperasiannya.

\section{DAFTAR PUSTAKA}

BPS. 2016. Provinsi Gorontalo dalam Angka Tahun 2016. Diakses dari www.gorontalo.bps.go.id

Nursyam, Marhawati, dan Max Nur Alam. 2013 Analisis Titik Pulang Pokok Usaha Virgin Coconut Oil (Vco) Pada IKM Pengais Jaya Di Desa Ampibabo Kecamatan Ampibabo
Kabupaten Parigi Moutong. E-J. Agrotekbis 1 (4) : 384-390

Susanti, Widjaja, dan Dewi. 2015 Pengaruh Waktu Sentrifugasi Krim Santan Terhadap Kualitas Virgin Coconut Oil (Vco). Jurnal Farmasi Udayana, ISSN 2622-460

Ni M. S, Manuntun M, Nadya, H. 2014. Uji Sifat Virgin Coconut Oil (Vco) Hasil Ekstraksi Enzimatis Terhadap Berbagai Produk Minyak Kelapa Hasil Publikasi Jurnal Udayana ISSN 1907-9850

Heny Herawati, Bram Kusbiantoro, Yayan Rismayanti, Mulyani. 2008. Pemanfaatan Limbah Pembuatan VCO Prosiding Seminar Nasianal Teknik Pertanian 2008 - Yogyakarta, 18-19 November 2008

Putra., R. R. 2012. Sintesis Hidrokarbon BerAngka Oktan Tinggi Dari Etanol Dengan Menggunakan Katalis Campuran Al2O3 Danhzsm-5. Skripsi. Universitas Indonesia 